\title{
Formation of Lifelong Learning Competences in the Process of Professional Training of Future Lawyers
}

\author{
Uliana Z. Koruts \\ Ternopil National Economic University \\ Ternopil, Ukraine \\ Valerii P. Petkov \\ Alfred Nobel University \\ Dnipro, Ukraine
}

Ehor S. Nazymko

Donetsk Law Institute of the Ministry of Internal Affairs of Ukraine (Kryvyi Rih)

Kryvyi Rih, Ukraine

Tetiana A. Denysova

International University "MITSO"

Gomel, Belarus

Uliana M. Oliinyk

Khmelnytsky University of Management and Law named after Leonid Yuzkov

Khmelnytsky, Ukraine

\begin{abstract}
The purpose of this study was to design and experimentally test the effectiveness of a model for the formation of lifelong learning competencies in future lawyers in higher educational institutions. The study presents the author's vision of the structure of lifelong learning competencies for lawyers identifies pedagogical conditions for the formation of lifelong learning competencies for lawyers. It is proved that the efficiency of formation of lifelong learning competences of future lawyers is considerably increased, provided that the basic types of active teaching methods and the latest information and computer technologies are used in the process of professional training. It is established that the most important pedagogical conditions for effective formation of lifelong learning competences are pedagogically-driven motivation of future specialists in the field of the right to formation and development of lifelong learning competences; introduction of methods that promote the formation and development of lifelong learning competences into the process of professional training; formation of professional qualities in future lawyers on the basis of conscious perception of the system of
\end{abstract}


universal and professional values. The authors argue that an effective link between employers and higher educational institutions is needed to collect and analyse structural and functional changes in professional activity. Establishing and maintaining such a link will enable higher educational institutions to respond more effectively to changes in the labour market requirements and to ensure a high level of training for their graduates.

Keywords: competence approach; lifelong learning competences; structure of competences; competence formation model; active teaching methods

\section{Introduction}

The determining characteristics of the current stage of development of the world educational space is that it is considered as a single organism, where separate educational systems are combined based on the manifestation of general global tendencies, while preserving national and linguistic differences, with traditions of cultural heritage being the ground. That is why nowadays, theorists and educators increasingly refer to international experience as a source of ideas for improving national educational policies in their search for effective ways of providing quality training for specialists in different areas. The term "lifelong learning" is undoubtedly one of the most commonly used terms in discussing problems of today's education and training. The very idea of lifelong learning as a tool for human capital development emerged in the second half of the last century (Becker, 1962). Although this educational approach was immediately criticized (Preston, 1999), the idea was actively discussed at various discussion sites, detailed and developed (Hager, 1998). The understanding of career development as "an evolution of the employee's consistent work experience over a period of time" is gradually being established in the world (Brown et al., 2010).

\subsection{Literature Review}

Since the end of the last century, EU Member States have aimed to develop the most competitive and dynamic common economy. In line with this objective, it was decided to strengthen cooperation in the field of initial professional training by supporting the widespread adoption of continuing professional education, and the European Qualifications Framework for lifelong learning was subsequently developed a (European Commission, 2008). Since then, the term "lifelong learning" does not leave the pages of scientific journals, varying slightly depending on the author's accentuation and focus - lifelong learning (Jakobi, 2009), lifewide learning/lifewide education (Jackson, 2012), lifelong education/lifelong learning (Barros, 2012), lifelong learning/adult education (Nemeth, 2015), etc. Lifelong learning has now become a key element in the determination of the European Union's strategies for building a developed knowledge-based society.

Research on a wide range of lifelong learning/education issues is being conducted worldwide (Zaitseva, 2009; Ng'asike, 2019; Zhou, 2019). Continuing education is seen as a priority factor, target and special value in the context of analysing the problems and prospects of human development (Gouthro, 2017). Current research 
shows that continuing education concerns not only the deepening and expansion of general education, professional competence, but also culture, education, the system of values and worldviews (Lee, 2019). The introduction of continuing education is a civilizational challenge to some extent. However, this process is successful if it is organizationally supported by a system of state and public institutions (Knight, 2018).

Our study found that at the current stage of development of the higher education system in Ukraine, the global requirements for the level of professional training and personality of the specialist are urged, which in turn determines the peculiarities of the formation of the personality structure of the student as a future specialist. In order to bring the national higher education system in line with world standards, reforms are needed, aimed at overcoming the highly specialized direction of the learning process, developing the personality of the specialist, creating effective systems for quality education throughout life and applying a competent approach to determining the quality of professional training of HEI's graduate. In Ukraine, current leading educational trends and ideas for the effective development of human potential are reflected in the Law of Ukraine on Higher Education (Legislation of Ukraine, 2014) and in a number of government documents (Karpenko, 2015).

While elaborating the problem of ensuring the quality of professional training of specialists in higher educational institutions, Ukrainian scholars agree that it is not enough to consider quality education only as a complex of knowledge, skills and abilities at the present stage of higher education development (Ziazun, 2001). Conceptual search ranged from "the graduate's desire for self-realization in life" (Gershunsky, 1998) to "self-awareness, moral health, education, active civic position" (Potashnik, 2000). However, fuzziness of terms and the complexity of their measurement have hindered their use as indicators of the quality of future specialists' training in higher educational institutions.

Bringing the national higher education system in line with world standards requires the establishment of effective quality lifelong learning systems and the use of a competent approach to determine the quality of professional training of a graduate of higher educational institutions. Professional development-oriented education and a competence-based approach to determining the quality of professional training of a graduate of a higher educational institution are currently the most effective means of bringing national higher education systems into line with world standards in the context of creating effective national lifelong learning systems (Merkulova, 2007; Isaienko \& Ilyina, 2011). In Ukrainian scientific and pedagogical thought, as well as in the world, readiness to implement the principles of continuing education is a mandatory criterion for assessing the quality of training (Holford, Hodge, Milana, Waller \& Webb, 2018) and the level of professional development (MacFarlane, 2019).

The aggregate scientific and theoretical achievements of Ukrainian scholars on the problems of reforming the national system of professional training of specialists in the context of changing the paradigm of "lifelong education" is extremely impressive: at the beginning of the century they developed the issues of bringing the higher education system of Ukraine in line with world standards (Zhuravsky 
\& Zgurovsky, 2003). However, partial issues of the above general problem are not sufficiently developed.

Interesting ideas on the introduction of a competence-based approach are suggested by researchers of ways of solving acute problems of professional training of modern educators (Khutorskoy, 2011), specialists in the medical field (Groenwold \& Knol, 2013), specialists in the field of engineering (Isaienko, 2007), physical education (Dereka, 2018), etc. At the present stage of development of Ukrainian higher legal education there is a need to develop theoretically sound, practically significant and convincing conceptual approaches to the organization of the system of continuing education for specialists in the field of law. Although there have been interesting studies on the implementation of the principles of continuing education in the training of lawyers (Babacan \& Babacan, 2018) over the past few years, theoretical and practical issues of ensuring an integrated system of continuing education and the application of a competency approach in the process of professional training of future lawyers remain insufficiently explored. At present, the conceptual vision of modern legal education in Ukraine is demonstrated by the recently drafted Legal Education Reform Concept (LigaZakon, 2019).

\subsection{Research Objective}

The high quality of professional training in the field of law is organically linked to the implementation of the principles and approaches of continuing education and a competent approach to the evaluation of the results of professional training in higher educational institutions. Given the paucity of theoretical and lack of practice-oriented research on the problem identified, the objective of this study is to design and experimentally test the efficiency of a model for the formation of lifelong learning competences in future lawyers in higher educational institutions.

To achieve this objectives, the following tasks were set:

- analyze the joint declarations adopted, the resolutions of the EU countries on the definition of key competences, and clarify the content and structure of lifelong learning competences of lawyers;

- distinguish pedagogical conditions of formation of lifelong learning competences, determine pedagogical technologies, methods and techniques effective for the formation of these competences for specialists in the field of law; - design a model for the formation of lifelong learning competences in future lawyers in higher educational institutions and test its effectiveness experimentally.

\section{Research methodology}

Continuity of learning in modern conditions appears as the principle of learning, the quality of the educational process and as a condition of personality formation (Billett, 2018). The key competences for lifelong learning, as outlined in the program (European Communities, 2007) and revised in the next recommendation (European Commission, 2018), are the basis for the reforms of the system of professional training of specialists in the European educational space. These competencies include: native language communication competence; foreign languages communication competence; digital competences; mathematical 
competence and basic competences in science and technology; learning competence; social and civic competences; competencies of initiative and entrepreneurship; competences in cultural awareness and ways of expression (European Communities, 2007). Based on the analysis of the EU documents in the field of education and science, scientific publications representing the views of world experts, scholars and practicing educators, the theoretical and methodological foundations of the research and the author's vision of the structure of lifelong learning competences of lawyers are formulated. In our study, we consider these key competencies as basic components for determining the structure of lifelong learning competences. The understanding that changes in professional structure, market needs, demands and/or wishes of employers have a huge impact on the structure and essence of lifelong learning competencies is equally important to us (Regmi, 2015; Kim \& Lee, 2020). Statement that the period of higher professional education is a period of formation of basic lifelong learning competences does not raise objections (Sachsenmeier, 1978).

The hypothesis of our study is based on the assumption that the use of pedagogical technologies, methods and techniques identified in the study in accordance with the specific pedagogical conditions in the process of professional training, will contribute to the formation and development of lifelong learning competences in future lawyers.

\subsection{Research design}

The study was carried out by several stages, each stage aimed at fulfilling the relevant tasks; the analysis of interim results was conducted after the completion of the tasks of each of the stages; the overall results were verified using statistical methods of data processing at the final stage of the study.

According to the research design, an analysis of philosophical, psychologicalpedagogical and legal sources was carried out at the first stage (March-May 2019) to establish the existing scientific approaches to the consideration of the concept of "lifelong learning competences" (Webb, Holford, Hodge, Milana \& Waller, 2017).

Scientific work on the peculiarities of the process of formation of lifelong learning competences, their subordination and the relationship with the formation and development of constituents of student personality structures have made important theoretical provisions for our study (Rybakina, 2018; Shin \& Jun, 2019). The work of Soares and Dias (2019) reaffirmed our understanding of the required changes in the content component of educational and professional programs implemented in higher educational institutions in the context of delivering the required learning outcomes. We extrapolated the provisions on the need to distinguish and study technological (Gough, 2017), motivational/value (Ilgaz \& Eskici, 2018) and communicative (Akmanova, Kurzaeva \& Kopylova, 2019) components in the professional training of specialists of different specialities to the process of professional training of lawyers, given the lack of such studies on law students.

At the next stage (June-September 2019), the authors formed a vision of the structure of lifelong learning competencies for lawyers (based on the review of publications on changes in the labour market, the structure of "skills" of a 
competitive specialist, the analysis of the requests and requirements of employers and supervisors of field and pregraduation practices as regards skills, qualities and level of professional training of future graduates of the universities of law) (Rappel, 2017; Boyadjieva, 2017). A total of 127 teachers, supervisors of field and pregraduation practices and employers were interviewed to fulfil the tasks of the study. Generalized wishes and requirements of employers and supervisors of field and pregraduation practices can be represented in several directions: 1) deep theoretical knowledge and practical skills of their application; 2) conscious perception of the system of universal and professional values; 3 ) professional and personal qualities (responsibility, initiative, ability to work in a team, aspiration for self-development, etc.). A comparison of the generalized wishes and requirements of employers and supervisors of field and pregraduation practices, key lifelong learning competences and the author's vision of the lifelong learning competency structure for law professionals is presented in Table 1.

Table 1: Comparing employers' general requirements, key lifelong learning competences and the author's vision of the lifelong learning competencies structure for lawyers

\begin{tabular}{|c|c|c|}
\hline $\begin{array}{c}\text { Generalized } \\
\text { requirements and } \\
\text { requests of employers } \\
\text { (formulated by the } \\
\text { authors based on the } \\
\text { results of the interview) }\end{array}$ & $\begin{array}{l}\text { Annex to the Proposal for } \\
\text { a Council } \\
\text { Recommendation on Key } \\
\text { Competences for Lifelong } \\
\text { Learning (European } \\
\text { Commission, 2018) }\end{array}$ & $\begin{array}{c}\text { Structure of lifelong learning } \\
\text { competences for lawyers } \\
\text { (author's vision) }\end{array}$ \\
\hline \multirow{4}{*}{$\begin{array}{l}\text { deep theoretical } \\
\text { knowledge and practical } \\
\text { skills for their } \\
\text { application }\end{array}$} & literacy competence & \multirow{2}{*}{$\begin{array}{l}\text { communicative competences } \\
\text { (ability to communicate } \\
\text { effectively in national, native } \\
\text { and foreign languages) }\end{array}$} \\
\hline & languages competence & \\
\hline & digital competence & $\begin{array}{l}\text { information competences } \\
\text { (computer skills; ability to } \\
\text { master the latest information } \\
\text { technologies) }\end{array}$ \\
\hline & $\begin{array}{l}\text { mathematical competence } \\
\text { and competence in } \\
\text { science, technology and } \\
\text { engineering }\end{array}$ & $\begin{array}{c}\text { cognitive competences } \\
\text { (logical, abstract and critical } \\
\text { thinking; ability to analyse, } \\
\text { synthesize, compare) }\end{array}$ \\
\hline $\begin{array}{l}\text { initiative; ability to } \\
\text { work in a team; } \\
\text { responsibility }\end{array}$ & $\begin{array}{l}\text { entrepreneurship } \\
\text { competence }\end{array}$ & $\begin{array}{l}\text { organizational and activity } \\
\text { competences (ability to } \\
\text { rationally distribute tasks, } \\
\text { plan time and activity; } \\
\text { ability to find and choose } \\
\text { effective ways of fulfilling } \\
\text { tasks) }\end{array}$ \\
\hline \multirow[b]{2}{*}{$\begin{array}{l}\text { conscious perception of } \\
\text { the system of human } \\
\text { and professional values }\end{array}$} & civic competence & \multirow{3}{*}{$\begin{array}{l}\text { competencies of self- } \\
\text { development and self- } \\
\text { realization }\end{array}$} \\
\hline & $\begin{array}{l}\text { cultural awareness and } \\
\text { expression competence }\end{array}$ & \\
\hline $\begin{array}{l}\text { aspiration for self- } \\
\text { development }\end{array}$ & $\begin{array}{l}\text { personal, social and } \\
\text { learning competence }\end{array}$ & \\
\hline
\end{tabular}


At the same stage of the study, pedagogical conditions for the formation of lifelong learning competencies were identified - pedagogically-driven motivation of future lawyers to form and develop lifelong learning competencies; introduction of methods that promote the formation and development of lifelong learning competences into the process of professional training; formation of professional qualities on the basis of conscious perception of the system of universal and professional values in future lawyers. The study identifies pedagogical technologies, methods and techniques that are effective in the formation of these competencies, namely - the main varieties of active learning methods - methods of modelling the features of professional activity during study (business games and business simulations, project method, case-study method with the preparation of individual or "team" reporting presentations), a method of step-by-step designing the process of fulfilling "production" tasks, a method of "algorithmizing" the decision-making process - and using the latest information and computer technologies in education. The authors of the study designed a model for the formation of lifelong learning competencies for lawyers, determined the criteria (motivational and axiological, content, organizational and technological, communicative) and levels (basic, secondary, sufficient, high) of the level of development of the said competences. An experimental model of the formation of lifelong learning competences in the process of professional training of future lawyers is schematically presented in Figure 1.

The next stage in the study was a pedagogical experiment conducted according to the traditional steps for this type of research: summative assessment (September 2019), realization of the formative assessment (September 2019 February 2020), final assessment (February 2020). At the final stage of the study, an analysis, comparison of the obtained results and verification of their validity were carried out with the use of the Student's test. 


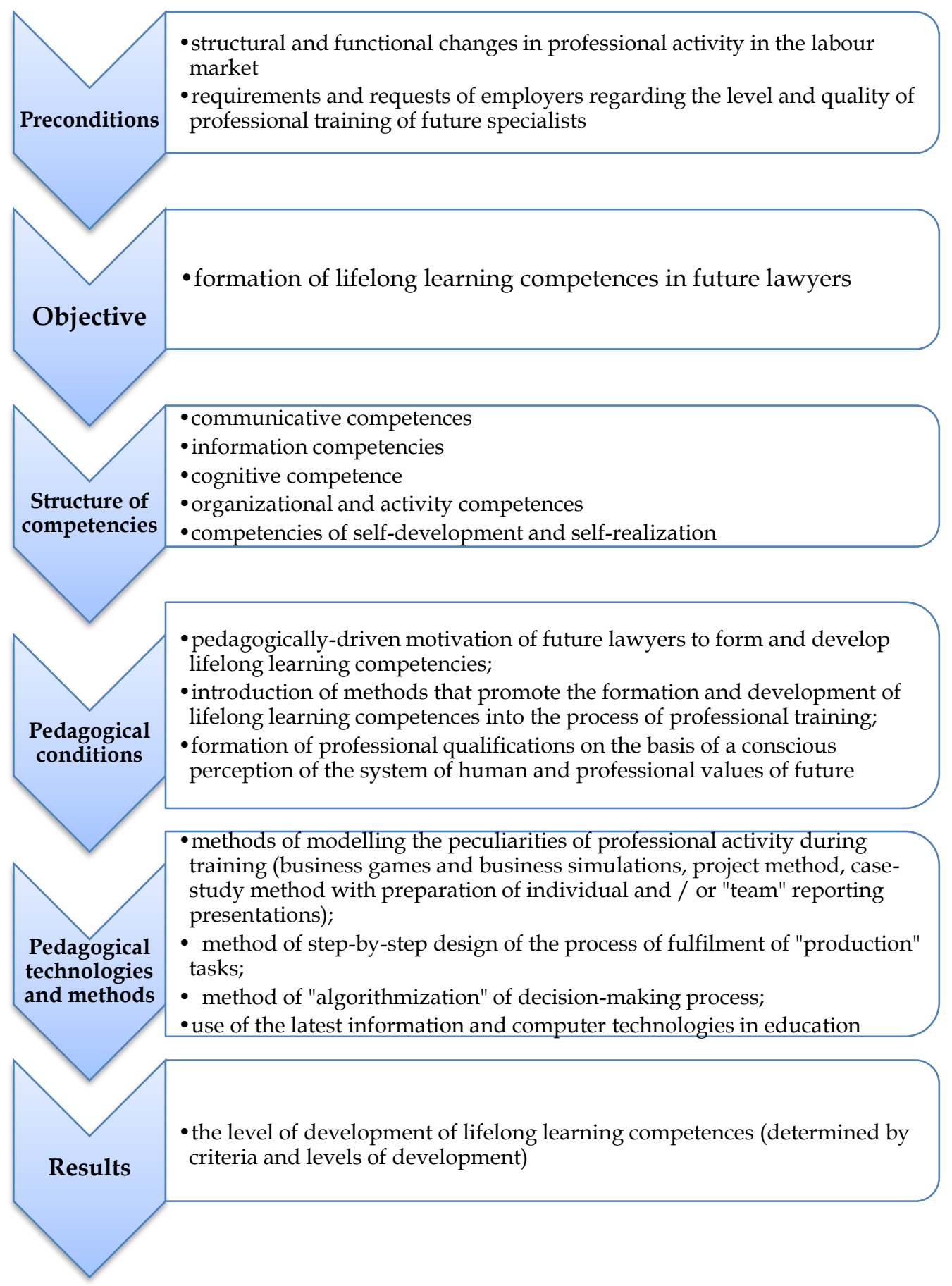

Figure 1: An experimental model for the formation of lifelong learning competences in the future professional training of lawyers

\subsection{Formation of research sample}

At the different stages of the study, a total of 276 students of the $2^{\text {nd }}$ year of the first (bachelor) level of education, Speciality 081 "Law" of the Chernihiv National University of Technology, Kherson Institute of the Economics and Law and the Academy of Labour, Social Relations and Tourism (Kyiv) were involved. A valid sample online calculator was used to generate the sample. For the 
abovementioned population of respondents (276), the size of a valid sample is 44 persons, which was taken into account in the formation of experimental (EG) and control (CG) groups. The experimental (EG) and control (CG) groups included 22 persons each. The comparative analysis was carried out within the existing academic groups, the students of the experimental and control groups studied according to typical programs. In the control group, lectures, seminars and practical classes were conducted according to typical methods, and in the experimental group - with the use of active teaching methods according to the peculiarities of training courses.

The results of the summative assessment carried out in the experimental and control groups are presented in Table 2.

Table 2: Comparison of initial levels of lifelong learning competences (summative assessment)

\begin{tabular}{|c|c|c|c|c|c|c|c|c|c|c|c|c|c|c|c|c|c|c|c|c|}
\hline & \multicolumn{20}{|c|}{ Lifelong learning competencies and levels of their development (\%) } \\
\hline & \multicolumn{4}{|c|}{$\begin{array}{l}\text { Communicative } \\
\text { competences }\end{array}$} & \multicolumn{4}{|c|}{$\begin{array}{l}\text { Information } \\
\text { competencies }\end{array}$} & \multicolumn{4}{|c|}{$\begin{array}{c}\text { Cognitive } \\
\text { competencies }\end{array}$} & \multicolumn{4}{|c|}{$\begin{array}{l}\text { Organizational } \\
\text { and activity } \\
\text { competences }\end{array}$} & \multicolumn{4}{|c|}{$\begin{array}{c}\text { Competencies of } \\
\text { self- } \\
\text { development/ } \\
\text { self-realization }\end{array}$} \\
\hline & . & פ్g & 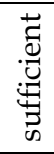 & . & $\begin{array}{l}\frac{u}{w} \\
\widetilde{\pi}\end{array}$ & 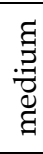 & 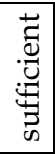 & 点 & $\begin{array}{l}\frac{u}{\tilde{d}} \\
\tilde{\Xi}\end{array}$ & 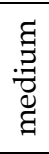 & 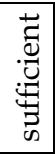 & 点 & 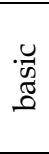 & ב્ּ & 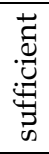 & .0.0 & 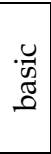 & 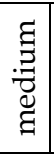 & 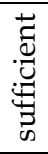 & .0. \\
\hline$\bigcup_{I I}$ & กै & @ & ৯ิ & L & L & 吕 & ○ & $\sigma$ & 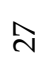 & กิ & 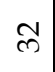 & $\sigma$ & $\stackrel{\sim}{\sim}$ & $\stackrel{\leftrightarrow}{+}$ & $\stackrel{\infty}{\sim}$ & a & $\stackrel{10}{\rightarrow}$ & ৯ & $\stackrel{a}{\rightarrow}$ & a \\
\hline U & ๓ & $\stackrel{2}{\rightarrow}$ & $\stackrel{\infty}{\sim}$ & 10 & L & के & 感 & $\sigma$ & ๗ँ & œ & ৯ิ & ח & $\stackrel{\sim}{\sim}$ & @ & הิ & $a$ & H) & ๙ै & $a$ & L \\
\hline
\end{tabular}

Comparison of the results of summative assessment in the experimental and control groups shows their similarity prior to the pedagogical experiment. The largest number of students in both groups showed the average level of communicative competencies, the second largest group of students with the basic level of this indicator, the third and fourth groups - students with sufficient and high level of communicative competencies, respectively. The two-tailed $p$-value for communicative competences equals 0.6453. By conventional criteria, this difference between the experimental and control groups is considered to be not statistically significant. We find a similar picture regarding the levels of organizational and activity competences. The two-tailed $p$-value for organizational and activity competences equals 0.5483 . By conventional criteria, this difference between the experimental and control groups is considered to be not statistically significant. More than half of the students in both groups showed a sufficient level of the development of information competencies, and more than a third showed a medium level of the development of the said competences. The share of students in the experimental and control groups with a high level of the development of information competency was $9 \%$, with a basic of $5 \%$ in each group. The two-tailed $p$-value for information competences equals 0.5689 . By conventional criteria, this difference between the experimental and control groups is considered to be not statistically significant. The largest number of students in 
both groups showed a medium level of cognitive competencies $(32 \%$ in the experimental group and $36 \%$ in the control group). A sufficient level of the development of cognitive competencies prior to the pedagogical experiment was established in $32 \%$ of the experimental group and $27 \%$ of the control group. Approximately one third of students demonstrated a basic level of cognitive competences (27\% in EG and 32\% in CG). The share of students with high levels of cognitive competence was less than $10 \%$. The two-tailed $p$-value for cognitive competences equals 0.7903 . By conventional criteria, this difference between the experimental and control groups is considered to be not statistically significant. The pattern of self-development and self-realization competencies in both groups is quite similar: approximately half of the students showed a basic level (45\% in the EC and $54 \%$ in the CG), about a third of the students had a medium level (27\% in the EC and 32\% in the CG), sufficient level was found in 19\% of the students in the experimental group and $9 \%$ in the control group; the high level was found in less than $10 \%$ of students in both groups. The two-tailed $p$-value for competencies of self-development/self-realization equals 0.4457 . By conventional criteria, this difference between the experimental and control groups is considered to be not statistically significant.

\subsection{Tools for collecting and processing statistics}

The data on the levels of the development of communicative competences were obtained through testing: Assessment of Communication Organizational Skills (Fetiskin, Kozlov \& Manuilov, 2012). The levels of the development of information competencies were determined by means of a survey: Studying the State of the Development of ICCs in Students (Feshchuk, 2009). Data on the level of the development of cognitive competencies in future lawyers were obtained through tests developed by the authors to determine the level of knowledge of students in special subjects. The questionnaire: Study of Different Types of Organizational Culture of R. Harrison (Lutens, 1999) was used to measure the level of the development of organizational and activity competencies. Data on the levels of students' self-development and self-realization competencies were determined with the use of the questionnaires of Zeer (2010).

Quantitative methods, such as evaluating and analysing test results of the students from both groups, questionnaires for students and teachers were used to achieve the research objective. STATA Software (n./d.) was used to analyse the quantitative data. 


\section{Results}

Following the pedagogical experiment, the final assessments were performed according to the diagnostics described above. Their results are presented in Table 3.

Table 3: Levels of the development of lifelong learning competences (after conducting the pedagogical experiment)

\begin{tabular}{|c|c|c|c|c|c|c|c|c|c|c|c|c|c|c|c|c|c|c|c|c|}
\hline & \multicolumn{20}{|c|}{ Lifelong learning competencies and levels of their development (\%) } \\
\hline & \multicolumn{4}{|c|}{$\begin{array}{l}\text { Communicative } \\
\text { competences }\end{array}$} & \multicolumn{4}{|c|}{$\begin{array}{l}\text { Information } \\
\text { competencies }\end{array}$} & \multicolumn{4}{|c|}{$\begin{array}{c}\text { Cognitive } \\
\text { competencies }\end{array}$} & \multicolumn{4}{|c|}{$\begin{array}{l}\text { Organizational } \\
\text { and activity } \\
\text { competences }\end{array}$} & \multicolumn{4}{|c|}{$\begin{array}{l}\text { Competencies } \\
\text { of self- } \\
\text { development/ } \\
\text { self-realization }\end{array}$} \\
\hline & $\begin{array}{l}\cdot \frac{\pi}{\pi} \\
\frac{\pi}{0}\end{array}$ & 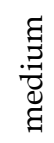 & 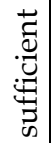 & . & $\begin{array}{l}. \frac{U}{D} \\
\frac{\pi}{\pi} \\
0\end{array}$ & 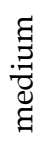 & 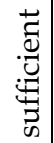 & 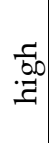 & 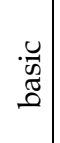 & 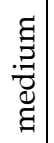 & 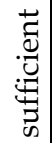 & 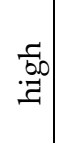 & 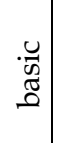 & 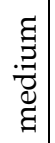 & 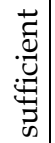 & $\underset{.00}{.00}$ & 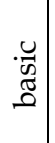 & 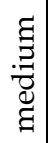 & 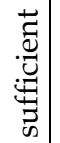 & .0.0 \\
\hline 蒫 & a & กิ & กै & $\widehat{\curvearrowright}$ & ' & $\stackrel{2}{N}$ & $\stackrel{\leftrightarrow}{+}$ & กै & a & 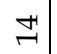 & in & $\stackrel{\infty}{\sim}$ & a & กै & $\stackrel{10}{\rightarrow}$ & $\rightleftarrows$ & 入ิ & 象 & 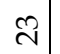 & $\underset{\rightleftarrows}{\sharp}$ \\
\hline $\mathcal{U}$ & 10 & 年 & 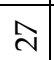 & $\mathscr{N}$ & 10 & $\stackrel{\infty}{\sim}$ & ถิ & $\stackrel{\infty}{\sim}$ & $\stackrel{\infty}{\sim}$ & $\stackrel{8}{q}$ & D & $a$ & $\stackrel{\infty}{\sim}$ & $\stackrel{10}{7}$ & ๗ี & 10 & F & గ & 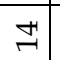 & $a$ \\
\hline
\end{tabular}

Comparison of indicators of the summative and formative stages of the pedagogical experiment shows that positive changes occurred in all lifelong learning competences in the students of both the experimental and control groups. The most noticeable changes are in the indicators of the levels of the development of cognitive competences in the experimental group. A share of students with a basic level decreased to $9 \%$ (while in the control group - to $18 \%$ ); with a medium level - decreased to $14 \%$ (while in the control group the indicator increased by $9 \%$ to $45 \%$ ); with a sufficient level - increased to $59 \%$ (in the control group - only to $36 \%)$; the proportion of students with high level of the development of cognitive competence in the experimental group increased twice (18\%) and in the control group increased by $4 \%$. The two-tailed $p$-value for cognitive competences equals 0.0245. By conventional criteria, this difference between the experimental and control groups is considered to be statistically significant.

The dynamics of positive changes in the levels of the development of communicative competences in the experimental and control groups are somewhat similar, although the indicators of the experimental group are better: after the pedagogical experiment, $9 \%$ of the students in the experimental group and $5 \%$ of the students in the control group showed the basic level; the proportion of students with a medium level of competence in the experimental group decreased by $4 \%$ (did not change in CG). The number of students with a sufficient level of communicative competences in both groups increased by less than $10 \%$, but students with a high level of communicative competence in both groups increased by almost $20 \%$. The two-tailed $p$-value for communicative competences equals 0.0234 . By conventional criteria, this difference between the experimental and control groups is considered to be statistically significant.

The analysis of changes in indicators of the levels of development of information competencies revealed a rather interesting picture. In the control group, the main "shifts" affected only the indicator of the average level of development of these competences (it decreased by 14\%). The indicator of the sufficient level increased 
by $5 \%$, of the high level increased by $9 \%$, and of basic level remained unchanged. At the same time, we observe the following dynamics in the experimental group: the basic level decreased by $5 \%$, the medium level decreased by $13 \%$, the sufficient level decreased by $5 \%$, and the high-level indicator increased by $23 \%$. The twotailed $p$-value for information competences equals 0.0392. By conventional criteria, this difference between the experimental and control groups is considered to be statistically significant.

Regarding the high level of the development of organizational and activity competencies after the pedagogical experiment, the indicators of the basic and medium levels decreased (by 18\% and 13\%, respectively), and the indicators of sufficient and high levels increased (by $23 \%$ and $5 \%$, respectively) in the experimental group. In the control group, the picture is slightly different: the basic level indicator lost $9 \%$, the medium and sufficient levels increased (by $9 \%$ and $4 \%$, respectively), and the high level decreased by $4 \%$. The two-tailed $p$-value for organizational and activity competences equals 0.0354 . By conventional criteria, this difference between the experimental and control groups is considered to be statistically significant.

The dynamics of changes in the levels of self-development and self-realization competencies in the experimental and control groups are similar: the basic level indicators lost $18 \%$ in the experimental and $14 \%$ in the control groups; medium, sufficient and high levels increased in the experimental group by $9 \%, 4 \%$ and $5 \%$, respectively, and in the control group - by $4 \%, 5 \%$ and $4 \%$, respectively. The twotailed $p$-value for competencies of self-development/self-realization equals 0.0149 . By conventional criteria, this difference between the experimental and control groups is considered to be statistically significant.

Statistical analysis of the results of the pedagogical experiment using the Student's test gave the value $t_{\text {experim }}=3.081$ at the value of $t_{\text {crit }}=2.0211$. Thus, the active teaching methods used in the experimental group during the pedagogical experiment have shown greater effectiveness in the formation of lifelong learning competencies in lawyers.

\section{Discussion}

After the final assessments, which generally confirmed the hypothesis of our study, we would like to make some comparison of the expected and obtained results of the conducted pedagogical experiment.

Figure 2 shows a graphical comparison of the results of the formative and postexperimental stages of the study. 


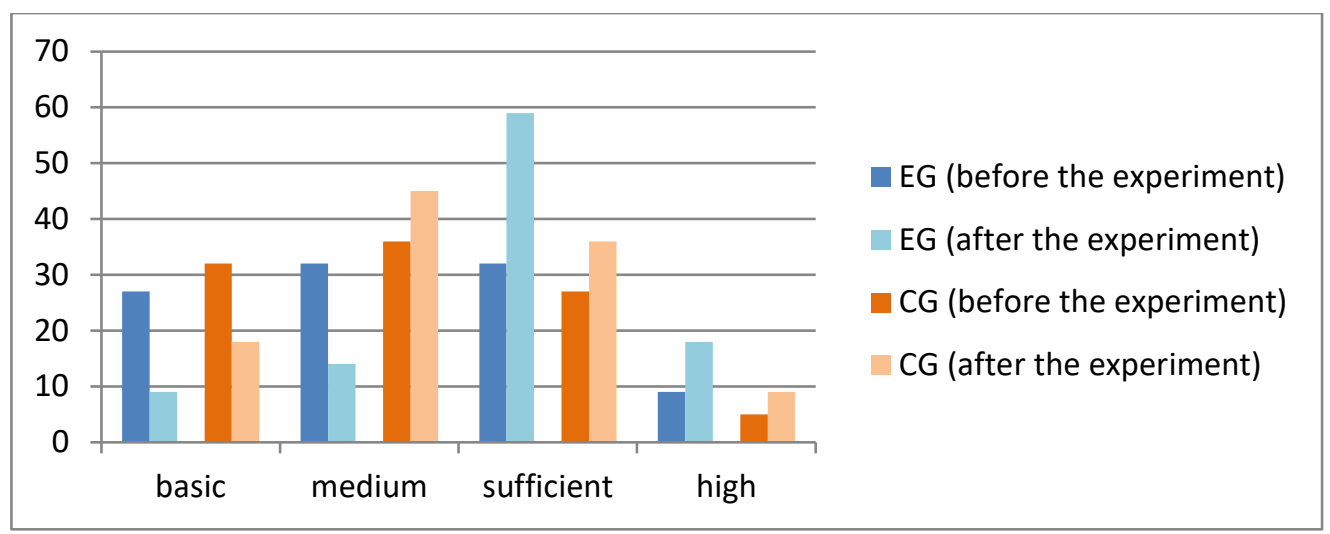

Figure 2: Dynamics of changes in levels of the development of cognitive competences in EG and CG students

As expected, the most noticeable shifts are recorded in the levels of the development of cognitive competence of future lawyers (Saccomanno, 2017). However, it should be noted that for a small period of pedagogical experiment, it is extremely difficult to develop the ability to analyse, synthesize, compare, or think logically, abstractly and critically in all students without exception. We can rather talk about effective improving of previously learned skills, or laying the foundations for further revealing cognitive competencies in future lawyers (Babacan \& Babacan, 2018). This statement is also supported by the fact that there were $9 \%$ of students with the lowest (basic) level of the development of cognitive competence after pedagogical experiment in the experimental group, and with high level of the development of cognitive competence - only $18 \%$ (9\% before the pedagogical experiment).

The positive changes in the levels of the development of communication competence in students of the experimental group were less impressive than we expected basing our expectations on modern studies (Homolová \& Vašašová, 2019). Their dynamics in shown in Figure 3.

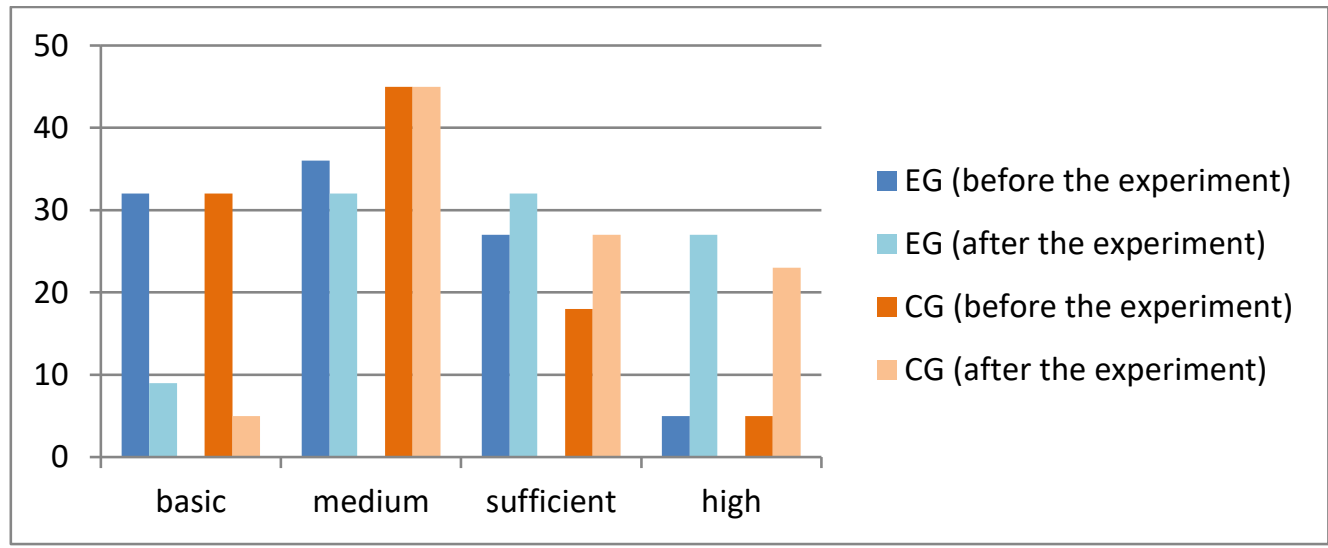

Figure 3: Dynamics of changes in levels of the development of communicative competences in EG and CG students

After analysing the data obtained and discussing it with the lecturers participating in the experiment, we can express our belief that the development of students' 
ability to communicate in the state and foreign languages requires more academic hours than stipulated in the curricula of the speciality. In addition, the indirect negative impact on the development of communicative competences (in particular, the ability to communicate effectively in the state language) also shows a lack of compliance with the legislation on the state language in higher educational institutions and other institutions (places of field and pregraduation practices).

The dynamics of changes in the level of the development of information competences generally coincided with our expectations (see Figure 4).

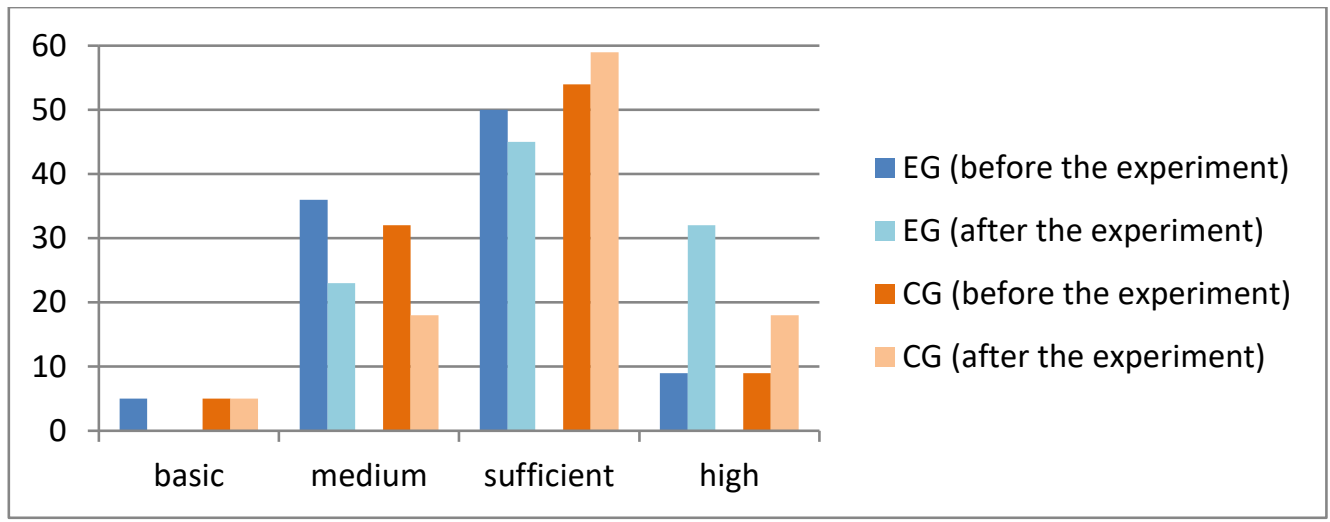

Figure 4: Dynamics of changes in levels of the development of informational competences in EG and CG students

However, the continuous improvement of information technologies, the emergence of new products and opportunities will require future lawyers to constantly improve their information competencies in order to maintain their developed level. This statement is no less significant in terms of the formation and development of organizational and activity competencies in future lawyers, despite the expected significant changes in the levels of their development in students of the experimental group. The dynamics of changes in the levels of organizational and activity competencies are clearly illustrated in Figure 5.

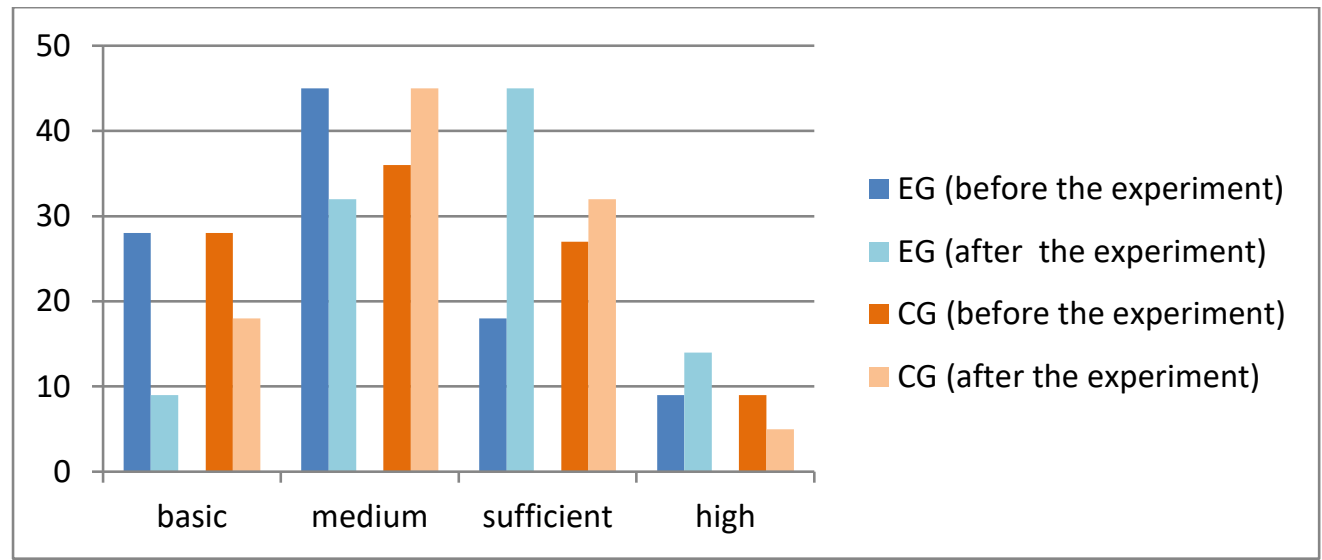

Figure 5: Dynamics of changes in levels of the development of organizational and activity competences in EG and CG students 
In our opinion, the competencies of self-development and self-realization are the most important in the structure of lifelong learning competences. It is this component of lifelong learning competencies that needs particular attention of researchers and high school educators (Smith, 2018). The dynamics of changes in the levels of self-development/self-realization competences are clearly demonstrated in Figure 6.

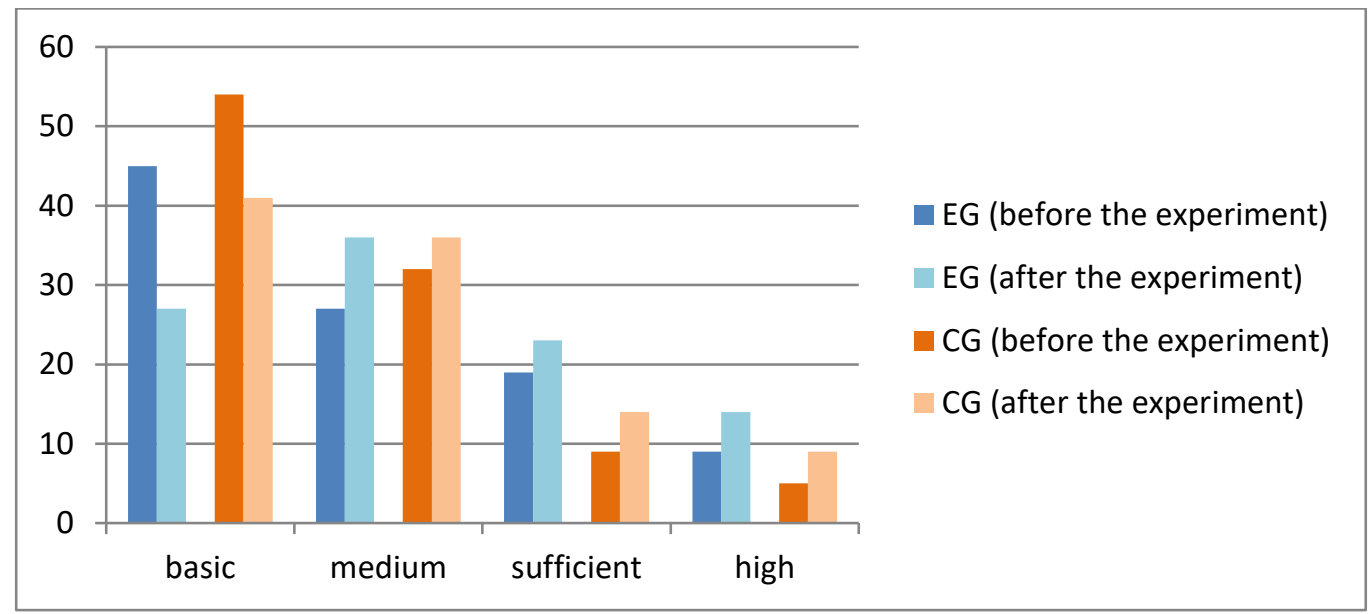

Figure 6: Dynamics of changes in levels of the development of self-development/selfrealization competences in EG and CG students

The changes in the indicators of the levels of self-development and self-realization competences recorded in the students of the experimental group at the final stage of our study are not very striking at first glance: more than half of the students showed the basic or medium level of the development of these competences (although the indicators of the experimental group significantly outperform those of the control group). We believe that the real "manifestation" of this structural component of lifelong learning competences is somewhat delayed, since it is at this stage of professional training of future lawyers (the first semester of the second year of the educational and professional program) that the competences of self-development and self-realization are formed in students. In addition, the limiting factors of this study stated above should also be considered in the analysis of the results achieved.

An experimental model of the formation of lifelong learning competences in students confirmed the importance of the pedagogical conditions identified in the study. However, the pedagogically-driven motivation of future lawyers to form and develop their lifelong learning competencies has proven to be both extremely important and extremely effective "lever" of activization of the students' position as regards the development of their lifelong learning competencies.

The greatest difficulty at the stage of preparation of pedagogical study was that there is a lack of convenient and proven effective methods of revealing changes in the requirements/requests of employers not only in the legal sphere, but also in other economic sectors. Moreover, feedback between higher educational institutions and institutions employing graduates is either currently ineffective or in need of adjustment or renewal. We believe that establishing links between employers and HEIs, developing similar methods of collecting such information 
and processing it, broad introducing the analysis of such information into the practice of higher educational institutions would allow HEIs to "tune" their educational and professional programs, improve the quality of future professional training and, ultimately, ensure the high competitiveness of their graduates. Finding effective approaches, methodologies, conducting systemic surveys and analysing them now requires the support and coordinated efforts of government agencies, HEIs and potential employers.

\section{Suggestions / Recommendations}

As one can see, the application of the experimental model of the development of lifelong learning competences of future lawyers has the greatest positive influence on the formation and development of cognitive, informational, organizationalactivity competences and competences of self-development and self-realization in students. In order to achieve higher levels of the development of communicative competence, further research is needed to identify ways to more effectively influence the process of forming and developing this structural component of lifelong learning competences. Diagnostics of measuring the levels of the development of individual structural components of lifelong learning competences also requires further research and development. An effective link between employers and higher educational institutions is also needed to collect (or exchange) and promptly analyse structural and functional changes in professional activity and changes in the labour market requirements for the professional characteristics (competencies) of the required specialists. Establishing and maintaining such a connection will enable higher educational institutions to respond more effectively to such changes and to ensure a high level of professional training for their graduates.

\section{Limitations}

It should be acknowledged that the main limiting factor in this study is the short time period of the pedagogical experiment (one academic semester). In addition, we have identified a lack of developed diagnostic techniques for the study of lifelong learning competencies, as well as prompt and effective ways to obtain information from employers about changing labour market needs.

\section{Conclusions}

The pedagogical conditions for the development of lifelong learning competences are distinguished; pedagogical technologies, methods and techniques effective for the development of these competences are determined; the model of the development of lifelong learning competences in a field of law is designed. Based on the analysis of the data obtained before and after the pedagogical experiment, the hypothesis was confirmed that the effectiveness of the formation of lifelong learning competences of future lawyers significantly increases provided the application of the main varieties of active teaching methods in the professional training process, namely - methods of modelling the peculiarities of professional activity during training (business games and business simulations, project method, case-study method with preparation of individual or "team" reporting presentations), the method of step-by-step fulfilment of "production" tasks, the 
method of "algorithmization" of the decision-making, and latest information and computer technologies. It is established that the most significant pedagogical conditions for the effective development of lifelong learning competences are pedagogically-driven motivation of future lawyers to form and develop lifelong learning competences; introduction of methods that promote the formation and development of lifelong learning competences into the process of professional training; formation of professional qualities in future lawyers on the basis of conscious perception of the system of universal and professional values.

\section{References}

Akmanova, S. V., Kurzaeva, L. V., \& Kopylova, N. A. (2019). Dynamic and Competence aspects of the media educational concept of developing a person's readiness for lifelong self-education. Informatics and education, 2, 23-33. https://doi.org/10.32517/0234-0453-2019-34-2-23-33

Babacan, A., \& Babacan, H. (2018). Repositioning lifelong learning in legal education. Widening Participation and Lifelong Learning, 20(2), 122-148. https://doi.org/10.5456/wpll.20.2.122

Barros, R. (2012). From lifelong education to lifelong learning. European Journal for Research on the Education and Learning of Adults, 3(2), 119-134. https://doi.org/10.3384/rela.2000-7426.rela0071.

Becker, G. S. (1962). Investment in human capital: A theoretical analysis. Journal of Political Economy, 70(5), 9-49.

Billett, S. (2018). Distinguishing lifelong learning from lifelong education. Journal of Adult Learning, Knowledge and Innovation, 2(1), 1-7. https://doi.org/10.1556/2059.01.2017.3

Boyadjieva, P. (2017). Gender, education and employment. An international comparison of school-to work transitions. International Journal of Lifelong Education, 36(5), 613616. https://doi.org/10.1080/02601370.2017.1304753

Brown, A., Bimrose, J., Barnes, S-A., Kirpal, S., Gronning, T., \& Dahlen, M. (2010). Changing patterns of working, learning and career development across Europe: final report. Brussels, Belgium: European Commission.

Dereka, T. G. (2018). Life-long physical education in the context of international integration processes (formal, nonformal, informal education). Scientific Journal of National Pedagogical Dragomanov University. Series 15. Scientific and pedagogical problems of physical culture (physical culture and sports), 3(97), 178-181.

European Commission. (2008). The European qualifications framework for lifelong learning (EQF). Luxembourg: Publications Office of the European Union.

European Commission. (2018). Annex to the Proposal for a Council Recommendation on Key Competences for Lifelong Learning. Retrieved from http://site.anc.edu.ro/wpcontent/uploads/2020/03/annex-recommendation-key-competences-lifelonglearning.pdf

European Communities. (2007). Key competences for lifelong learning: European Reference Framework. Luxembourg: Publications Office of the European Union.

Feshchuk, Y. V. (2009). Methods of development of spatial thinking of future teachers of technologies by means of computer graphics (PhD thesis). National University of Life and Environmental Sciences of Ukraine, Kyiv, Ukraine.

Fetiskin, N. P., Kozlov, V. V., \& Manuilov, G. M. (2012). Socio-psychological diagnosis of the development of personality and small groups. Moscow, Russia: Publishing House of the Institute of Psychotherapy. 
Gershunsky, B. S. (1998). The philosophy of education for the 21st century (in search of practiceoriented educational concepts). Moscow, Russia: Sovershenstvo.

Gough, J. (2017). The usefulness of useless knowledge. International Journal of Lifelong Education, 36(5), 616-621. https://doi.org/10.1080/02601370.2017.1322780

Gouthro, P. A. (2017). The promise of lifelong learning. International Journal of Lifelong Education, 36(1-2), 45-59. https://doi.org/10.1080/02601370.2017.1270067

Groenwold, R. H., \& Knol, M. J. (2013). Learning styles and preferences for live and distance education: an example of a specialisation course in epidemiology. BMC Medical Education, 13, Article 93. https://doi.org/10.1186/1472-6920-13-93

Hager, P. (1998). Lifelong Education: From Conflict to Consensus? Studies in Philosophy and Education, 17, 323-332. https://doi.org/10.1023/A:1005163702740.

Holford, J., Hodge, S., Milana, M., Waller, R., \& Webb, S. (2018). University renewal: “The times they are a-changing"? International Journal of Lifelong Education, 37(2), 147150. ttps://doi.org/10.1080/02601370.2018.1467669

Homolová, E., \& Vašašová, Z. (2019). Changes in motivation factors in language education of senior learners. Lifelong Learning, 9(2), 23-38. https://doi.org/10.11118/lifele20190902023

Ilgaz, G., \& Eskici, M. (2018). Examination of teacher candidates' lifelong learning competence and basic motivation resources as parts of sustainability. Sustainability, 11(1), 23. https://doi.org/10.3390/su11010023

Isaienko, S. A. (2007). Competent approach in the formation of professional culture in students of higher technical education. The Pedagogical Process: Theory and Practice, $4,47-54$.

Isaienko, S. A., \& Ilyina, O. V. (2011). The competence and competence of a specialist in the context of his professionalism. Scientific Herald of NULES of Ukraine. Series: Pedagogics, psychology, philosophy, 159(4), 209-215.

Jackson, N. (2012). Lifewide learning: History of an idea. Retrieved from https://pdfs.semanticscholar.org/895b/38ff95929fcd58ee5fb14c43b54a9b3b5c02. pdf

Jakobi, A. (2009). Global education policy in the making: International organisations and lifelong learning. Globalisation, Societies and Education, 7(4), 473-487.

Karpenko, M. M. (2015). "Life-long education as a factor in human development." Analytical note. National Institute for Strategic Studies. Retrieved from http://www.niss.gov.ua/articles/1865/

Khutorskoy, A. V. (2011). Definition of general subject matter and key competencies as a characteristic of a new approach to the construction of educational standards. Bulletin of the Institute for Human Education, 1. Retrieved from http://xn-h1am1a.xn--p1ai/journal/2011/Eidos-Vestnik2011-103-Khutorskoy.pdf

Kim, H., \& Lee, Y. (2020). A structural model of customer relationship management (CRM) strategies, rapport, and learner intentions in lifelong education. Asia Pacific Education Review, 21, 39-48. https://doi.org/10.1007/s12564-019-09583-3.

Knight, E. (2018). Responding to massification: differentiation in postsecondary education worldwide. International Journal of Lifelong Education, 37(3), 384-386. https://doi.org/10.1080/02601370.2018.1437964

Lee, W. W. S. (2019). Nexus between massification of tertiary education and community college students' learning experiences in Hong Kong. International Journal of Lifelong Education, 38(5), 527-537. https:// doi.org/10.1080/02601370.2019.1654001

Legislation of Ukraine. (2014). Law of Ukraine: On Higher Education. Retrieved from http://zakon4.rada.gov.ua/laws/show/1556-18/print1389899592029395 
LigaZakon. (2019). Legal education reform concept (Draft). Retrieved from https://ips.ligazakon.net/document/nt4472.

Lutens, F. (1999). Organizational change and development. Organizational behavior. Moscow, Russia: Digital.

MacFarlane, K. (2019). Building capabilities for higher education prior to entry. Widening Participation and Lifelong Learning, 21(3), 5-31. https://doi.org/10.5456/wpll.21.3.5

Merkulova, S. V. (2007). The problem of assessing the quality of training: a competencybased approach. Higher education in Russia, 8, 127-130.

Nemeth, B. (2015). Lifelong learning for all adults? A new concept for the United Nations educational, scientific and cultural organization - limits and opportunities for a changing intergovernmental organization. In M. Milana \& T. Nesbit (Eds.), Global perspectives on adult education and learning policy (pp. 165-178). London, UK: Palgrave Macmillan.

Ng'asike, J. T. (2019). Indigenous knowledge practices for sustainable lifelong education in pastoralist communities of Kenya. International Review of Education, 65, 19-46. https:// doi.org/10.1007/s11159-019-09767-4.

Potashnik, M. M. (ed.). (2000). Quality management of education: a practice-oriented monograph and methodological manual. Moscow, Russia: Pedagogical Society of Russia.

Preston, R. (1999). Critical approaches to lifelong education. International Review of Education, 45, 561-574. https://doi.org/10.1023/ A:1003835209787.

Rappel, L. (2017). Workplace learning as a spiritual practice. International Journal of Lifelong Education, 36(5), 541-550. https:// doi.org/10.1080/02601370.2017.1306891

Regmi, K. A. (2015). Lifelong learning: Foundational models, underlying assumptions and critiques. International Review of Education, 61, 133-151. https://doi.org/10.1007/s11159-015-9480-2.

Rybakina, N. A. (2018). Educational competence: the essence and pedagogical model of formation in the context of lifelong education. The Education and Science Journal, 20(5), 32-55. https://doi.org/10.17853/1994-5639-2018-5-32-55

Saccomanno, B. (2017). The aims of lifelong learning through the dynamic of ambition. International Journal of Lifelong Education, 36(5), 551-564. https:// doi.org/10.1080/02601370.2017.1312579

Sachsenmeier, P. (1978). Basic education as the first stage of lifelong education: Aspects of a working concept for curriculum integration and educational development in third world countries. International Review of Education, 24, 153-166. https://doi.org/10.1007/BF00598977.

Shin, Y.-S., \& Jun, J. (2019). The hierarchical effects of individual and organizational variables on elementary school teachers lifelong learning competence. International Electronic Journal of Elementary Education, 12(2), 205-212. https:// doi.org/10.26822/iejee.2019257668

Smith, R. (2018). Self-construction and social transformation: lifelong, lifewide and lifedeep learning. International Journal of Lifelong Education, 37(3), 393-395. https://doi.org/10.1080/02601370.2018.1456031

Soares, D., \& Dias, D. (2019). Perspectives of lifelong education in Portuguese higher education: a critical analysis of learning outcomes. International Journal of Lifelong Education, 38(2), 148-156. https://doi.org/10.1080/02601370.2018.1559890

STATA Software. (n./d.). Retrieved from https://www.stata.com/

Webb, S., Holford, J., Hodge, S., Milana, M., \& Waller, R. (2017). Lifelong learning for quality education: exploring the neglected aspect of sustainable development goal 4. International Journal of Lifelong Education, 36(5), 509-511. https://doi.org/10.1080/02601370.2017.1398489 
Zaitseva, O. V. (2009). Continuous education: main definitions and terminology. Tomsk State Pedagogical University Bulletin, 7(85), 106-110.

Zeer, E. F. (2010). Personally-developing technologies of primary vocational education: a training manual. Moscow, Russia: Publishing Center "Academy".

Zhou, X. (2019). Establishment of a lifelong education system. In G. Zhou \& X. Zhou (Eds.), Education Policy and Reform in China (pp. 95-103). Singapore: Palgrave Macmillan. https://doi.org/10.1007/978-981-13-6492-1_8.

Zhuravsky, V. S., \& Zgurovsky, M. Z. (2003). The Bologna Process: Basic Principles for Entering the European Higher Education Area. Kyiv, Ukraine: Polytechnica.

Ziazun, I. A. (2001). Continuing education as the basis of social progress. Continuing Professional Education: Theory and Practice, 1, 15-23. 


\section{Appendix 1 \\ Questionnaire for Teachers, Supervisors of Internship and Externship and Employers of Lawyers}

Please answer some questions

1. Please specify the current needs of the legal market for the training of specialists in the field of law.

2. What should be the ideal law school graduate? Offer a list of personal and professional qualities.

3. Evaluate on the proposed scale, what, in your opinion, are the chances of law graduates to get the necessary work immediately after graduation ( 3 points the highest chances, 0 points - the lowest):

\section{$3-2-1-0$}

4. We kindly ask you to evaluate the importance of the proposed components of the culture of professional communication of specialists in the field of law in future practical professional activities on a three-point scale, taking into account the degree of necessity of their use in solving professional problems:

3 - "extremely necessary in the legal activity"

2 - "desirable in the legal activity",

1 - "will not spoil legal activity",

0 - "a lawyer does not need it".

\begin{tabular}{|c|c|c|c|c|c|}
\hline Knowledge & \multicolumn{5}{|c|}{ Rating } \\
\hline psychological characteristics of an individual and the team & 0 & 1 & 2 & 3 & \\
\hline factors of efficiency and optimization of professional communication & 0 & 1 & 2 & 3 & other \\
\hline $\begin{array}{l}\text { possible ways (ways) of resolving conflict situations in professional } \\
\text { activity of a lawyer; }\end{array}$ & 0 & 1 & 2 & 3 & other \\
\hline $\begin{array}{l}\text { the concept of etiquette, its role in professional communication, } \\
\text { features of the etiquette of a lawyer, its basic rules and functions }\end{array}$ & 0 & 1 & 2 & 3 & other \\
\hline \begin{tabular}{|l} 
Skills and Abilities \\
\end{tabular} & & & Rat & & \\
\hline \multicolumn{6}{|l|}{ Information skills } \\
\hline find information & 0 & 1 & 2 & 3 & other \\
\hline identify the main point in the message & 0 & 1 & 2 & 3 & other \\
\hline find arguments & 0 & 1 & 2 & 3 & other \\
\hline formulate questions and answers & 0 & 1 & 2 & 3 & other \\
\hline draw conclusions & 0 & 1 & 2 & 3 & other \\
\hline express clearly and competently & 0 & 1 & 2 & 3 & other \\
\hline control voice & 0 & 1 & 2 & 3 & other \\
\hline use non-verbal means of communication & 0 & 1 & 2 & 3 & other \\
\hline \multicolumn{6}{|l|}{\begin{tabular}{|c} 
Perceptual skills \\
\end{tabular}} \\
\hline assess one's own condition at the time of communication & 0 & 1 & 2 & 3 & other \\
\hline catch the interlocutor's mood & 0 & 1 & 2 & 3 & other \\
\hline anticipate the partner's appropriate response & 0 & 1 & 2 & 3 & other \\
\hline $\begin{array}{l}\text { determine how conditions (time, place) promote or hinder } \\
\text { communication }\end{array}$ & 0 & 1 & 2 & 3 & other \\
\hline restrain emotions & 0 & 1 & 2 & 3 & other \\
\hline
\end{tabular}




\begin{tabular}{|c|c|c|c|c|c|}
\hline \multicolumn{6}{|l|}{ Interactive skills } \\
\hline establish contact with the interlocutor & 0 & 1 & 2 & 3 & other \\
\hline maintain contact during communication & 0 & 1 & 2 & 3 & other \\
\hline convince the interlocutor & 0 & 1 & 2 & 3 & other \\
\hline formulate orders & 0 & 1 & 2 & 3 & other \\
\hline subject the position of the interlocutor to argumentative criticism & 0 & 1 & 2 & 3 & other \\
\hline organize a group solution to the problem & 0 & 1 & 2 & 3 & other \\
\hline \multicolumn{6}{|l|}{ General legal skills } \\
\hline knowledge of the rules of law & 0 & 1 & 2 & 3 & other \\
\hline operate with legal terminology & 0 & 1 & 2 & 3 & other \\
\hline know the basics of public speaking & 0 & 1 & 2 & 3 & other \\
\hline draw up procedural documents & 0 & 1 & 2 & 3 & other \\
\hline \multicolumn{6}{|l|}{ Specialized legal skills } \\
\hline $\begin{array}{l}\text { knowledge of forms of documents (depending on the type of legal } \\
\text { activity) }\end{array}$ & 0 & 1 & 2 & 3 & other \\
\hline enclosing the necessary content in the wording & 0 & 1 & 2 & 3 & other \\
\hline make accents depending on the position & 0 & 1 & 2 & 3 & other \\
\hline knowledge of medical, accounting, technical, economic terminology & 0 & 1 & 2 & 3 & other \\
\hline ability to speak abstractly & 0 & 1 & 2 & 3 & other \\
\hline ability to express oneself clearly, in essence & 0 & 1 & 2 & 3 & other \\
\hline $\begin{array}{l}\text { knowledge of procedures (court hearings, forms of concluding } \\
\text { agreements, conducting investigative work, examinations) }\end{array}$ & 0 & 1 & 2 & 3 & other \\
\hline
\end{tabular}

5. We kindly ask you to evaluate the level of professional legal knowledge, skills of young specialists with experience in the legal field of up to 3 years on a three-point scale.

3 - "perfectly"

2 - "sufficient level",

1 - "weak level",

0 - "do not know".

\begin{tabular}{|c|c|c|c|c|c|}
\hline Knowledge & \multicolumn{5}{|c|}{ Rating } \\
\hline psychological characteristics of an individual and the team & 0 & 1 & 2 & 3 & other \\
\hline $\begin{array}{l}\text { factors of efficiency and optimization of professional } \\
\text { communication }\end{array}$ & 0 & 1 & 2 & 3 & other \\
\hline $\begin{array}{l}\text { possible ways (ways) of resolving conflict situations in } \\
\text { professional activity of a lawyer; }\end{array}$ & 0 & 1 & 2 & 3 & other \\
\hline $\begin{array}{l}\text { the concept of etiquette, its role in professional communication, } \\
\text { features of the etiquette of a lawyer, its basic rules and functions }\end{array}$ & 0 & 1 & 2 & 3 & other \\
\hline $\begin{array}{l}\text { Skills and abilities } \\
\end{array}$ & & & Rati & & \\
\hline \multicolumn{6}{|l|}{ Information skills } \\
\hline find information & 0 & 1 & 2 & 3 & other \\
\hline identify the main point in the message & 0 & 1 & 2 & 3 & other \\
\hline find arguments & 0 & 1 & 2 & 3 & other \\
\hline formulate questions and answers & 0 & 1 & 2 & 3 & other \\
\hline draw conclusions & 0 & 1 & 2 & 3 & other \\
\hline express clearly and competently & 0 & 1 & 2 & 3 & other \\
\hline control voice & 0 & 1 & 2 & 3 & other \\
\hline use non-verbal means of communication & 0 & 1 & 2 & 3 & other \\
\hline
\end{tabular}




\begin{tabular}{|c|c|c|c|c|c|}
\hline \multicolumn{6}{|l|}{ Perceptual skills } \\
\hline assess one's own condition at the time of communication & 0 & 1 & 2 & 3 & other \\
\hline catch the interlocutor's mood & 0 & 1 & 2 & 3 & other \\
\hline anticipate the partner's appropriate response & 0 & 1 & 2 & 3 & other \\
\hline $\begin{array}{l}\text { determine how conditions (time, place) promote or hinder } \\
\text { communication }\end{array}$ & 0 & 1 & 2 & 3 & other \\
\hline restrain emotions & 0 & 1 & 2 & 3 & other \\
\hline \multicolumn{6}{|l|}{ Interactive skills } \\
\hline establish contact with the interlocutor & 0 & 1 & 2 & 3 & other \\
\hline maintain contact during communication & 0 & 1 & 2 & 3 & other \\
\hline convince the interlocutor & 0 & 1 & 2 & 3 & other \\
\hline formulate orders & 0 & 1 & 2 & 3 & other \\
\hline subject the position of the interlocutor to argumentative criticism & 0 & 1 & 2 & 3 & other \\
\hline organize a group solution to the problem & 0 & 1 & 2 & 3 & other \\
\hline \multicolumn{6}{|l|}{ General legal skills } \\
\hline knowledge of the rules of law & 0 & 1 & 2 & 3 & other \\
\hline operate with legal terminology & 0 & 1 & 2 & 3 & other \\
\hline know the basics of public speaking & 0 & 1 & 2 & 3 & other \\
\hline draw up procedural documents & 0 & 1 & 2 & 3 & other \\
\hline \multicolumn{6}{|l|}{ Specialized legal skills } \\
\hline $\begin{array}{l}\text { knowledge of forms of documents (depending on the type of } \\
\text { legal activity) }\end{array}$ & 0 & 1 & 2 & 3 & other \\
\hline enclosing the necessary content in the wording & 0 & 1 & 2 & 3 & other \\
\hline make accents depending on the position & 0 & 1 & 2 & 3 & other \\
\hline $\begin{array}{l}\text { knowledge of medical, accounting, technical, economic } \\
\text { terminology }\end{array}$ & 0 & 1 & 2 & 3 & other \\
\hline ability to speak abstractly & 0 & 1 & 2 & 3 & other \\
\hline ability to express oneself clearly, in essence & 0 & 1 & 2 & 3 & other \\
\hline $\begin{array}{l}\text { knowledge of procedures (court hearings, forms of concluding } \\
\text { agreements, conducting investigative work, examinations) }\end{array}$ & 0 & 1 & 2 & 3 & other \\
\hline Skills & \multicolumn{5}{|c|}{ Rating } \\
\hline Psychological rapid diagnosis of personality traits of citizens; & 0 & 1 & 2 & 3 & other \\
\hline Effective communication; & 0 & 1 & 2 & 3 & other \\
\hline Resolving conflict situations that arise in professional activities; & 0 & 1 & 2 & 3 & other \\
\hline $\begin{array}{l}\text { Evaluation of one's actions and the actions of others in terms of } \\
\text { ethics and morality }\end{array}$ & 0 & 1 & 2 & 3 & other \\
\hline $\begin{array}{l}\text { Behaviour in the team and communication with citizens in } \\
\text { accordance with the rules of etiquette; }\end{array}$ & 0 & 1 & 2 & 3 & other \\
\hline Psychological (legitimate) influence on an individual. & 0 & 1 & 2 & 3 & other \\
\hline
\end{tabular}

Thank you for participating! 